\title{
The Baltic States and international development cooperation: how can they best share their transition experience with less advanced transition countries?
}

The Baltic States are in a transition from being recipient countries to becoming donor countries. The article argues that small states like the Baltic States can play an important role in economic development like, for example, the Nordic countries ${ }^{1}$, but in a different way. The Baltic States have recent and relevant transition experience to share that can be valuable for less advanced transition countries, but they are challenged by small development budgets. The article concludes that the Baltic States can increase their development impact by engaging in policy dialogue with their partner countries ${ }^{2}$ which should be supported with technical assistance projects and capacity building projects.

Keywords: Small states, bilateral and multilateral development cooperation, budget support, policy dialogue, international financial institutions (IFIs).

Baltijos valstybès yra pereinamajame laikotarpyje, kuomet iš pagalbą gaunančiųjų šalių jos tampa valstybemis donorèmis. Straipsnyje teigiama, jog mažos Baltijos valstybės, kaip ir Šiaurès šalys, gali vaidinti svarbų vaidmenį ekonomikos plètrai, tik naudodamos kitas priemones. Baltijos valstybès turi naujausią ir tiesiogiai susijusią pereinamojo laikotarpio patirți, vertingą mažiau išsivysčiusioms pereinamojo laikotarpio šalims. Straipsnyje teigiama, jog Baltijos valstybès gali pagreitinti savo vystymosi procesą, ịsitraukiant ị politinị dialogą su šalimis partnerèmis, kurios turètų būti remiamos technine pagalba bei gebẻjimus stiprinančiais projektais.

Raktiniai žodžiai: mažos valstybès, dvišalio ir daugiašalio vystymosi bendradarbiavimas, biudžeto parama, politinis dialogas, tarptautinès finansinès institucijos (TFI).

JEL Classifications: O20/O19/O40.

\section{Introduction}

In spite of many challenges faced by the Baltic States during the recent economic and financial crisis, their progress since independence in 1991 has been remarkable. In about two decades those countries have been transformed from being centrally planned economies and part of the former
Soviet Union, into modern countries that are firmly integrated into the global economy. Since the independence they have become members of the European Union (EU), NATO and the World Trade Organization (WTO). ${ }^{3}$ They are also members of international financial institutions like the 
World Bank Group (WBG) and the European Bank for Reconstruction and Development (EBRD). According to World Bank classifications Latvia and Lithuania are upper middle income countries and Estonia has achieved a high income status (World Bank, 2012a).

Nordic countries like Denmark, Norway and Sweden have also been affected by the economic and financial crisis but in spite of being relatively small countries they remain among donor countries that could be classified as leaders in development cooperation and are among few countries in the world who contribute more than $0.7 \%$ of their GDP to international development cooperation ${ }^{4}$. In addition to large bilateral development programs they are active members in international financial institutions such as the WBG, EBRD as well as in all the regional development banks. ${ }^{5}$

When reconsidering and developing their foreign aid programs it can be useful for the Baltic States to review the experience of these neighbouring countries to see what lessons can be learned from their experience.

Multilaterally the Nordic Countries and the Baltic States already cooperate extensively. At the World Bank Group the Baltic States share an Executive Director's Office with the Nordic Countries. This Nordic-Baltic cooperation also extends to the European Bank for Reconstruction and Development (EBRD). At the EBRD Iceland shares an office with Estonia and Sweden, Latvia works with Norway and Finland, and finally Lithuania works with Denmark $^{6}$ (European Bank for Reconstruction and Development, 2011). Nordic countries, especially Denmark, Norway and Sweden, are leaders in international development cooperation and as a group can have an impact on development policy and development approaches worldwide. When cooperating with the Baltic States the Nordic countries could also benefit from the experience of the Baltic States who have recently implemented successful economic transitions.

The objective of this article is to assess what role small states can play in assisting their partner countries in their efforts to implement economic transition, achieve economic growth and poverty reduction. The countries focused on are mainly the Baltic States. As discussed above all those countries are participants in multilateral institutions and provide bilateral assistance to the partner countries they have selected. But how should they as small states assist their partner countries in the future? How can the Baltic States best share their transition experience with less advanced transition countries? Should they focus on small bilateral projects or should they work in partnership with other bilateral and multilateral donors? Should they engage in budget support operations and participate in policy dialogue or concentrate on small projects, or some combination of both?

Asking those questions now may sound strange since the Baltic States are still affected by the economic and financial crisis that started in 2008. However all these countries have their ongoing development cooperation programs and like larger countries they need to think about the effectiveness of the programs they support with their limited resources. In addition to this, the Baltic States as EU member states are currently challenged by their obligations as EU members to increase their contributions to international development cooperation. The target was to increase their official development assistance (ODA) to $0.1 \%$ of GNI by 2010 and $0.33 \%$ of GNI by 2015. 
The Baltic States, EU11 and EU15: Economic growth prospects

\begin{tabular}{|l|c|c|c|}
\hline & $\mathbf{2 0 1 1}$ & $\mathbf{2 0 1 2}$ & $\mathbf{2 0 1 3}$ \\
\hline Estonia & 7.6 & 1.7 & 3.0 \\
\hline Latvia & 5.5 & 2.3 & 2.9 \\
\hline Lithuania & 5.9 & 2.3 & 3.5 \\
\hline EU11 & 3.1 & 1.5 & 2.5 \\
\hline EU15 & 1.5 & -0.1 & 1.2 \\
\hline
\end{tabular}

Source: World Bank, 2012b.

It seems clear that in the coming years the contributions of the Baltic States to international development cooperation will increase substantially, especially when their economies return to pre-crisis growth levels. In fact, the June 2012 World Bank EU11 Regular Economic Report projects healthy economic growth rates for all the Baltic States in the near future (World Bank, 2012b), higher than average among EU11 countries (EU11: Bulgaria, Croatia, the Czech Republic, Estonia, Hungary, Latvia, Lithuania, Poland, Romania, Slovenia, Slovak Republic), and well beyond growth in the EU15 countries (EU15: Austria, Belgium, Denmark, Finland, France, Germany, Greece, Ireland, Italy, Luxembourg, the Netherlands, Portugal, Spain, Sweden and the United Kingdom) (see Table 1).

The aim of the article is to draw the attention of policy makers in the Baltic States, who are in the process of formulating their development programs, to recent trends in international development cooperation. Studying these trends and the way other small states, including the Nordic countries, have implemented their development programs, can help the Baltic States increase the effectiveness of their programs. The other aim of the article is to contribute to the academic literature on Baltic international development cooperation. Very little has been written so far in this area and more research and discussion in schools in the Baltic States could help policy makers shape these programs in the future.

The method used it the article is the case study method and this is a comparative case study involving the three Baltic States. The study is based on a review of theoretical literature, interviews, email exchanges, secondary data and the author's previous experience as a staff member of the World Bank Group and as Special Advisor to the Foreign Minister of Iceland. The methodology is discussed in more detail below.

\section{Methodology}

The methodology used in the article is the case study method. Compared to other research methods, a case study enables the researcher to examine the issues at hand more in-depth. According to R. K. Yin (2009) there are six sources of evidence that are most commonly used in doing case studies. Those are: documentation, archival records, interviews, direct observations, participant-observation, and physical artefacts. Each of these sources has advantages and disadvantages and according to R. K. Yin (2009, p. 101-102) 
one should "note that no single source has a complete advantage over all the others. In fact, the various sources are highly complementary, and a good case study will therefore want to use as many sources as possible".

Among the sources of evidence used for the analysis in this article are documentation/secondary data, including reports and scholarly literature. The author also exchanged emails with and interviewed various experts in the field, including in the ministries responsible for international development cooperation in the Baltic States. These communications when referred to are documented in notes at the end of the article. Direct observation also plays a role in this article as the author draws on his experience and observations having worked in the Baltic States for the World Bank Group for four years, from 1999 to 2003, while they were implementing transition just before EU accession. Preference was given to using well documented evidence that is publicly available and listed in the references. However one needs to keep in mind that there is hardly any scholarly literature on the subject.

This comparative case study does not present results that can be evaluated on the basis of statistical significance and one should be careful in generalizing findings of one case study on another case or situation. However, some lessons from the study can have a wider relevance then just for the Baltic States. This is especially true for small countries that have implemented economic transition, successfully and sometimes unsuccessfully, and wish to share their experience with other less advanced transition countries, but have limited financial sources to do so.

\section{Public awareness and support for development cooperation in the Baltic States}

As discussed before the economics of the Baltic States are growing and there is an expectation within the EU that they as member states increase their contributions to international development cooperation. But is there public support for international development cooperation within the Baltic States?

According to the Eurobarometer 2012 survey public support for development cooperation is rather strong in the Baltic States. The 2012 survey shows that $85 \%$ of Lithuanians, $80 \%$ of Latvians and $73 \%$ Estonians consider it important "to help people in developing countries." However, $35 \%$ of Lithuanians, $29 \%$ of Latvians and $23 \%$ of Estonians considered it very important "to help people in developing countries" (European Commission, 2012, p. 8). This support for development cooperation is notable because the Baltic States were hit hard by the global economic and financial crisis, especially Latvia. However, this support is lower than it was in 2010 according to the 2010 Eurobarometer survey (European Commission, 2010). ${ }^{7}$

Do the Baltic States see added value in having EU Member States working together on helping developing countries? According to Eurobarometer 2010 survey there is a notable difference on the level of importance the Baltic States attach to having the EU countries working together. Estonia has the strongest support for EU cooperation or $84 \%$, Latvia - $78 \%$ and Lithuania - $54 \%$. In spite of this difference the majority of people feel that there is value added in having EU Member States working together on helping developing 
The Baltic States and their priority partner countries

Table 2

\begin{tabular}{|l|c|c|c|}
\hline & Country & Income level & GNI per capita, US\$ \\
\hline \multirow{3}{*}{$\begin{array}{l}\text { Estonia: Development } \\
\text { cooperation - priority } \\
\text { partner countries }\end{array}$} & Afghanistan & Low income & 585 \\
& Georgia & Lower middle income & 2.860 \\
& Moldova & Lower middle income & 1.980 \\
& Ukraine & Lower middle income & 3.120 \\
& Armenia & Lower middle income & 3.360 \\
Latvia: Development & Azerbaijan & Upper middle income & 5.290 \\
cooperation priority & Belarus & Upper middle income & 5.830 \\
countries & Georgia & Lower middle income & 2.860 \\
& Moldova & Lower middle income & 1.980 \\
& Ukraine & Lower middle income & 3.120 \\
\hline \multirow{2}{*}{ Lithuanian: Priority par- } & Afghanistan & Low income & 585 \\
tner countries & Belarus & Upper middle income & 5.830 \\
& Georgia & Lower middle income & 2.860 \\
& Moldova & Lower middle income & 1.980 \\
& Ukraine & Lower middle income & 3.120 \\
\hline
\end{tabular}

Source: World Bank 2012a, Ministry of Foreign Affairs, Latvia 2012, Ministry of Foreign Affairs, Estonia 2012, Ministry of Foreign Affairs, Lithuania 2012.

countries by responding to the question either with "yes, definitely" or "yes, to some extent" (European Commission, 2010, p. 14).

In the 2010 Eurobarometer survey 49 $\%$ of Estonians, $57 \%$ of Latvians and $65 \%$ Lithuanians either felt that the EU should either increase aid to developing countries beyond what has already been promised or keep their promise to increase aid (European Commission 2010). However, the citizens of the Baltic States do not seem to know much about where aid goes? In Latvia, for example, $63 \%$ say they know nothing about where their national aid goes, while $54 \%$ say they know nothing regarding EU aid. The pattern is similar for Estonia (national: $60 \%$, EU: $57 \%$ ), Lithuania (national: 61 \%, EU: 52 \%) (European Commission, 2010). Thus here is little awareness about development cooperation programs in general in spite of support for development cooperation.

\section{The Baltic States and partner country selection}

If one takes a look at where the bilateral development assistance that the Baltic States provide goes, it is clear that most of the priority partner countries are lower middle income economies in Europe and Central Asia (see Table 2).

Currently Estonia supports Afghanistan, Georgia, Moldova, Ukraine, Armenia and Azerbaijan as priority partner countries (Ministry of Foreign Affairs, Estonia, 2012). Latvia selected Belarus, Georgia, Moldova and Ukraine as its development cooperation priority countries (Ministry of Foreign Affairs, Latvia, 2012). Lithuania supports Afghanistan, Belarus, Georgia, Moldova and Ukraine as priority partner countries (Ministry of Foreign Affairs, Lithuania, 2012).

The Baltic States have thus chosen share their experience with less advanced transition countries further to the south 
and the east in Europe and Central Asia, including some of their neighbours. With this country selection the Baltic States are contributing to economic development, peace promotion and stability in the region they live in and are part of. What is unique with the selection of the priority countries of the Baltic States is that those are mainly middle income, not the poorest low income countries. This is common for the country selection of EU10 countries (the Czech Republic, Estonia, Hungary, Latvia, Lithuania, Poland, Slovakia, Slovenia as well as Bulgaria and Romania) but is very different from EU15 countries that emphasize assistance to low income countries, particularly in Sub-Saharan Africa, where the Baltic States are not yet active. The only exception to this middle income focus is Afghanistan which is a low income country and this support is probably related to NATO membership of the Baltic States.

\section{Contributions to international development cooperation and EU commitments}

The Baltic States as who joined the EU in 2004 are currently challenged by their obligations as EU members to increase their contributions to international development cooperation. The target was to increase their ODA (official development assistance) to $0.17 \%$ GNI by 2010 and 0.33 $\%$ of GNI by 2015 . According to preliminary numbers provided by the Council of the European Union for 2011, none of the EU10 countries has reached the target of $0.17 \%$ of GNI, which they were supposed to reach in 2010. Lithuania had reached $0.13 \%$ of GNI, Estonia $0.12 \%$ of GNI, Latvia $0.07 \%$ GNI (see Figure 1).

While one can expect those programs to grow until 2015 it seems unlikely that any of the Baltic States will be able to reach

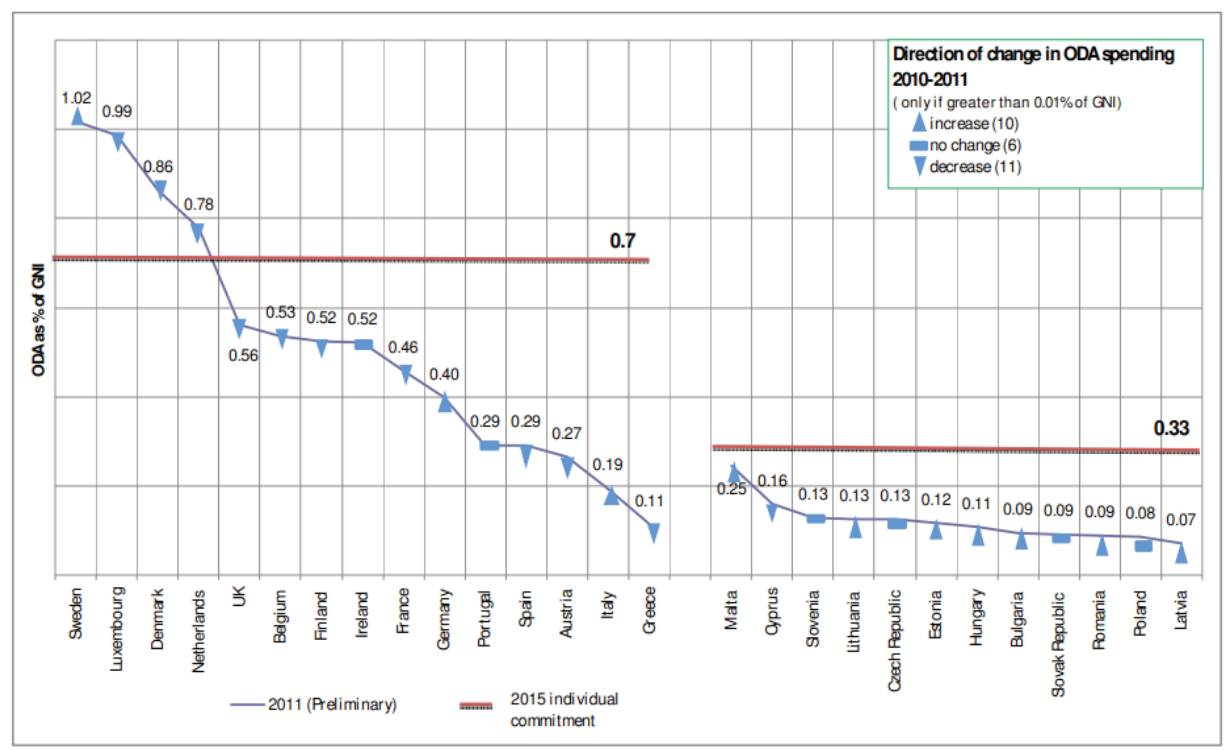

Fig. 1. Gap between 2011 ODA levels and 2015 agreed individual targets of the 27 EU Member State and direction of change from 2010 to 2011

Source: Council of the European Union, 2012. 
Table 3

Funds allocated for development cooperation and humanitarian aid in the state budget of Estonia* through 2010-2015 (EUR million per annum)

\begin{tabular}{|l|c|c|c|c|c|c|}
\hline & $\mathbf{2 0 1 0}$ & $\mathbf{2 0 1 1}$ & $\mathbf{2 0 1 2}$ & $\mathbf{2 0 1 3}$ & $\mathbf{2 0 1 4}$ & $\mathbf{2 0 1 5}$ \\
\hline GNI & 13,502 & 14,147 & 14,850 & 15,613 & 16,442 & 17,026 \\
\hline $\begin{array}{l}\text { \% of GNI (Government proposal } \\
\mathbf{1 3 . 0 5 . 2 0 1 0 )}\end{array}$ & 0.104 & 0.119 & 0.143 & 0.149 & 0.162 & 0.176 \\
\hline $\begin{array}{l}\text { Total official development coope- } \\
\text { ration and humanitarian aid funds }\end{array}$ & 14.00 & 16.97 & 21.31 & 23.28 & 26.76 & 30.06 \\
\hline
\end{tabular}

* Estonia is the only Baltic State so far that has developed such multiyear plan for its international development cooperation.

Source: Estonian Government (n.d.).

$0.33 \%$ of GNI by 2015. In fact, Estonia, the only Baltic State that has a multiannual plan for its contributions for development cooperation, plans to reach $0.176 \%$ of GNI by 2015 (see Table 3 ).

Given their income level and economic growth, the Baltic States need to consider seriously how they can move closer to the EU target. Not only the EU10 countries fall short of fulfilling their commitment in their contributions, but most EU15 countries also fall short of their $0.7 \%$ of GNI target and in fact only Sweden, Luxembourg, Denmark, Netherlands, all small states, fulfill this commitment.

\section{Project approach and budget support. Some definitions and theoretical considerations}

What approach should the Baltic States choose for their development cooperation: project approach or budget support, or a combination of both? The answer to this question has in part to do with what strength they have and what they want to offer to their partner countries.

The so called project approach means that the donor country, in this case the Baltic States, define sector specific project, with an agreed timetable, in cooperation with the receiving country, but the financial administration of the project is maintained within donor country. This level of donor involvement is out of line with the mainstream approach in international development cooperation as it is conducted today, emphasizing country ownership and using the planning, budgetary and procurement systems of the receiving/ partner country. ${ }^{8}$ Internationally there has been discussion and emphasis on budget support to recipient countries, and on assisting them in creating an overall policy environment conducive to long-term economic growth.

One way for the Baltic States to share their transition experience is to become active in the policy dialogue with their partner countries. This could be done by shifting some of the resources from the projects currently dominating their bilateral aid programs to provision of budget support in partnership with other donors. As S. Koeberle and Z. Stavreski (2006, p. 3) note "Budget support has become an increasingly important mode of development assistance, receiving growing attention from bilateral donors and international financial institutions in the context of a partnership-based approach to aid. This form 
of aid promises benefits for both donors and recipient countries: increasing scope for scaling up development assistance, reducing transaction costs, strengthening country ownership, and achieving greater development effectiveness than traditional modes of aid delivery." This is especially noteworthy for the Baltic States as their comparative advantages lie in sharing their recent transition experience with less advanced transition countries. Policy advice cannot only be prescriptive and based on standardized development models but should assist countries in developing their own solutions for applying principles that have been recognized as valid development approaches. Consultations with successful transition countries, like the Baltic States, that have recently implemented similar reforms, can aid in the process that needs to be undertaken by less advanced transition countries.

But what exactly is budget support? A variety of definition can be found. In a recent World Bank publication S. Koeberle and Z. Stavreski (2006, p. 3) define budget support as "financial assistance that supports a medium-term program and is provided directly to a recipient country's budget on a regular basis, using the country's own financial management systems and budget procedures". According to OECD DAC Guidelines and Reference Series budget support is defined as „a method of financing a partner country's budget through a transfer of resources from an external financing agency to the partner government's national treasury. The funds thus transferred are managed in accordance with the recipient's budgetary procedures" (OECDa, 2006, p. 26). According to the European Commission "budget support is a way of implementing development aid which consists in giving financial aid to the treasuries of the recipient countries. This aid increases the resources available to the recipient country to implement its own budget according to its own procedures. What generally characterises budget support is that it goes directly to the partner governments and is integrated into their own systems of appropriation, procurement and accounts, and is not connected to specific projects" (European Commission, 2008, p. 15).

Common to all these definitions is the notion of direct financial support to the partner country's budget. Given the current size of the Baltic economies these transfers cannot be large in absolute terms but they would allow the Baltic States to participate in a broad based dialogue and share their transition experience. In fact many donors consider an opportunity for an open dialogue on broad policy reforms to be one of the most important elements of budget support arrangements. As S. Koberle and Z. Stavresky (2006, p. 20) emphasize "Smaller bilateral donors, in particular, value the opportunity to contribute effectively to the dialogue on government policies". It is important that the policy dialogue between donors and the partner country is well informed and supported by well targeted analytical work and technical assistance. Here some of the small technical assistance and capacity building projects provided by the Baltic States could become more effective if they supported specific policy actions.

Given the recent trends internationally one may ask the question whether or not the time has come for small countries like the Baltic States to engage in policy dialogue with developing countries and provide a direct budget support in partnership with other donors, including small states, as well as international financial institutions. Many donors, including the other Nordic 
Priority sectors/areas of the Baltic States in their partner countries

Table 4

\begin{tabular}{|l|l|l|}
\hline \multicolumn{1}{|c|}{ Estonia $^{9}$} & \multicolumn{1}{c|}{ Latvia $^{10}$} & \multicolumn{1}{c|}{ Lithuania $^{11}$} \\
\hline (i) Education and health (human & (i) Fostering market economy & (i) Promotion of democracy; \\
development); & (international trade and DCFTA & (ii) Rule of law and human rights; \\
(ii) Good governance and demo- & standards and requirements); & (iii) Economic development; \\
cratization; & (ii) Promoting good governance & (iv) Euro-integration processes; \\
(iii) Sustainable economic develop- & (civil society, local governments, & (v) Administrative capacity \\
ment (including environment); & state administration reforms); & building. \\
(iv) Horizontal field: ITC. & (iii) Environment; & \\
\hline
\end{tabular}

Sources: Ministry of Foreign Affairs Estonia 2011, Ministry of Foreign Affairs Latvia 2011, Ministry of Foreign Affairs Estonia 2011.

Countries, are involved in budget support and use it as means to engage in policy dialogue with the developing country and to help the government of the receiving country to take the lead and ownership of the overall policy reform in the country. In fact according to a recent World Bank Independent Evaluation Group (IEG) PRSC evaluation the Nordic countries are among the biggest bilateral budget support providers in several African countries. In 2007 Sweden was for example among top three bilaterals providing budget support to countries like Tanzania, Mozambique, Burkina Faso, Rwanda and Mali. The same year Norway was among the top 3 bilaterals providing budget support to Uganda and Malawi and Denmark was among 3 top bilaterals in budget support to Benin (World Bank, 2010a).

Although the Baltic States may initially use the project approach when they assist other countries they may soon also want to consider budget support and engage in policy dialogue. This may be important for them since they, as new EU member states, are committed to increase their ODA to 0.17 \% GNI by 2010 and $0.33 \%$ of GNI by 2015 . As the aid volumes increase project approach may become too time consuming and out of line with the practice used by other donors. What distinguishes the Baltic States from the Nordic countries is that their priority countries are mainly middle income countries where as the Nordic countries focus mainly on low income countries. In fact, as noted above, the EU10 countries tend to support middle income countries whereas the EU15 countries focus on low income countries. This makes sense for the Baltic States, as they have recent transition experience to share, that is particularly relevant for middle income countries and in their assistance they focus on priority transition issues (see Table 4).

However budget support operations like the PRSC's that Nordic Countries have participated in, only support low income IDA countries. Another World Bank Institution, IBRD that supports middle income countries provides budget support via Development Policy Loans (DPL). Donor harmonization is needed for both instruments, PRSC and DPL.

\section{Partner countries and policy dialogue}

Some of the partner countries of the Baltic States have recently been receiving budget support via Development Policy Loans 
(DPL) or Development Policy Operations (DPO) from the World Bank in partnership with other bilateral donors and multilateral institutions.

The World Bank Country Partnership Strategy for Georgia for the financial years 2010-2013 (FY10-FY13) reports a series of three annual DPOs, within a programmatic framework that will provide both immediate budget support to the Government while supporting reforms in selected areas - improving public finances, strengthening social safety nets, and building external competitiveness. According to the World Bank the cross-sectorial content of the DPOs and their leveraging of budget support operations from other partners, such as the Netherlands, Asian Development Bank (AsDB) or the European Commission (EC) will give them high prominence. The World Bank also highlights the benefits of the programmatic approach, not just for budget support operations but also on the analytic side, to deliver just-intime advice, and this practice will, according to the bank, continue throughout the program (World Bank, 2009).

According to the World Bank's Economic Recovery Development Policy Credit 2010,

Moldova receives development funding from several multilateral and bilateral donors in collaboration with the World Bank. The policy notes that supported the DPL operation's dialogue with the Moldovan government were developed jointly with the United Nations (UN), the International Monetary Fund (IMF), the European Union (EU), the UK Department for International Development (DFID), and the Swedish International Development Cooperation Agency (SIDA). Complementing the IMF and Bank operations, the $\mathrm{EU}$ is providing budget support of EUR
50 million to contribute to the sustainable economic development of rural areas, as envisaged under the EU-Moldova Action Plan (World Bank, 2010b). Thus the DPL operation's dialogue with Moldova is developed jointly with multilateral institutions and bilateral donors, i.e.: the UN, IMF, EU, DFID and SIDA. In addition to this the EU provides budget support to a joint EU-Moldova Action Plan.

Georgia and Moldova are both priority countries of all the Baltic States and are undertaking reforms that are often similar to the reforms that the Baltic States implemented in the past. Why are the Baltic States not active in supporting those reform efforts? Countries like the Netherlands, Sweden and the UK are involved, but they never have implemented transition from communist central planning to market economy. Nevertheless the contribution of Netherlands, Sweden and the UK can be, and probably is, very important but the Baltic transition experience is undoubtedly more relevant for Georgia and Moldova.

It is important to note that budget support is not always appropriate. In the World Bank Country Partnership Strategy for Ukraine for the financial years 20122016 (FY12-FY16) the World Bank states that "inconsistent implementation of past reforms and significant governance problems create unacceptable risks for the Bank to provide direct budget support" (World Bank, 2012c, p. 17). According to the World Bank the authorities in Ukraine are aware of the need for more consistency and have committed themselves to a program of addressing some of the most prominent governance concerns, including: public procurement, VAT refunds, transparency in the energy sector, business regulation and red tape, and government investments into failed financial institutions. 
The government and the World Bank will jointly evaluate progress in these areas to determine whether DPL lending can be resumed (World Bank, 2012c).

The Baltic States could, like the Netherlands, the UK, and Sweden, participate in some budget support operations such as those described above in countries like Georgia and Moldova, or in other European and Central Asian partner countries. They are already participating in budget support operations multilaterally as members of the World Bank, including with their contributions to the World Bank's International Development Association (IDA) and the European Union's European Development Fund (EDF). Some government officials in the Baltic States that were contacted when this article was under preparation, however, seemed rather discouraged. One government official, for example, stated that Estonia only had 1 vote out of 720 in the EDF and did thus not "have much weight in the decision making process." ${ }^{2}$ An official from Lithuania simply stated: "We do participate in the EDF coordination process." ${ }^{13}$ A Lithuanian official reported "cases of sectorial budget support in Afghanistan" as well as policy dialogue in Belarus in partnership with the Swedish International Development Agency (SIDA) in Belarus. ${ }^{14}$ It seems like lack of funding discourage the governments of those three small countries and in spite of relevant transition experience they hesitate to participate.

In a recent article E. Andrespok and A. I. Kasekamp (2012) refer to a conference paper (Hilmarsson, 2011) as follows "Former World Bank official H. T. Hilmarsson (2011) argues that the Baltic States should follow the Nordic states and switch form their small projects based approach in bilateral assistance to budget support and policy dialogue with the recipient countries, through which, he believes, they can maximize their impact. While this approach might indeed bring the Baltic States in line with the general trend among international donors, it undervalues the significances of new donor countries being able to show their flags and thereby build up public support for development cooperation expenditure." (Andrespok and Kasekamp, 2012, p. 122). This statement is based on a misunderstanding of budget support. If the Baltic States participate in budget support their primary goal would be increase their effectiveness by sharing their recent experience via such dialogue. This could increase their visibility. At the same time they could support policy actions they favor with some of their smaller technical assistance or capacity building projects. Also if they engage in policy dialogue for example on education reform or health reform, this could be complimented with support on building a school or a hospital. Thus the world is not black or white here, i.e., only budget support or only project approach. Each can support the other. They key question, however, is what combination is most effective for the Baltic States given their valuable experience in reform and limited budget resources.

\section{Small donors and policy dialogue - some cases}

Does it make sense for small donors to shift from projects and provide a broad based support to their partner countries in cooperation with other larger donors? When analyzing the cases of Austria and Ireland, both small states, and their participation in Programme-Based Approaches (PBAs) L. Leyser (2008) "finds that a shift 
towards PBAs actually seems to be more important for small bilateral donors than for large ones" (Leyser, 2008, p. 2). According to L. Leyser (2008, p. 34) "PBAs enable small donors to 'punch above their weight' in terms of influence and to realize endeavors that would be impossible alone". Commenting on the Irish experience L. Leyser (2008) argues that "the most remarkable effect of Iris PBA engagement has been its lead position in most of the PBAs it participates. PBAs make Irish Aid "bigger" relative to its share of funding" (Leyser, 2008, p. 3). The case of Ireland can be looked at as an example of a small country influence when working in partnership with other larger donors.

Small donors like the Baltic States may still be uncertain whether or not to shift toward budget support due to their relatively small aid budgets and low capacities compared with larger donors. Small donors maybe concerned that their voice will not be heard if they provide assistance in partnership with larger donors. They may fear the possible loss of identity and visibility.

But small donors can also have an advantage due to their comparatively neutral and not-threatening nature which may enhance their leadership credentials as other larger donors and governments are willing to support them. Small donors like the Baltic States have no colonial ties. They can have important expertise. The Baltic States, for example, have recently implemented successful transition. Small donors can also have an important role as brokers between larger donors and the partner country and facilitate harmonization. Leadership in a donor group by countries like the Baltic States would hardly ever be considered threatening to any other donor country or the partner country receiving assistance.

For small donors projects can certainly allow them plant their flag and to better control the use of their money. But in the big picture of things, the impact of small projects may be quite marginal. Policy lending under a PRSC-like umbrella gives small donors a seat at the table for the policy dialogue. However, a small country would probably be most effective if it focuses only on a few key policy actions. A small donor country may also increase its impact by combining involvement in budget support with technical assistance for the ministries or agencies in charge of those key policy actions. The partner country receiving the technical assistance can then rely on the products of that technical assistance as an input in the policy dialogue, and on technical assistance program itself to deliver on the policy actions (e.g. drafting of a decree).

In a recent IEG $^{15}$ evaluation of World Bank PRSCs the bank even complains that "Individual small donors can sometimes unduly influence the agenda" (World Bank 2010a, p. 43). This study also notes that "Budget support groups often have uneven membership with a few large core donors and a large number of smaller donors, as well as nonfinancing members, which find it desirable to have a seat at the table" (World Bank 2010a, p. 48) and "in the case of Vietnam, donors complain that the Bank sometimes appears too demanding for small donors and suggests a more effective division of labor toward donors who have expertise in a sector" (World Bank 2010a, p. 56). When participating in PRSCs small donors may thus want to be selective in the actions they propose and support those actions with technical assistance to increase their impact. Small 
donors, like the Baltic States, can thus influence beyond their monetary contribution if they are technically competent and well prepared. The World Bank and other international financial institutions should welcome such engagement.

\section{Budget support and fiduciary risks}

Some donors, such as the Baltic States, may be hesitant to engage in budget support because of the perceived fiduciary risks involved. But is there any reason to believe that budget support is necessarily more prone to corruption than investment projects? There seems to be no research that settles this issue unambiguously. To begin with, fiduciary risk seems hard to measure in any rigorous way. An Evaluation of General Budget Support (19942004 ) is the title of an independent report carried out by the University of Birmingham on behalf of more than thirty donor and partner countries. It was initiated and supported by the OECD's Development Assistance Committee's Evaluation Network. According to the OECD "The team of evaluators found no clear evidence that budget support funds were, in practice, more affected by corruption than other forms of aid" (OECD 2006b, p. 1). Furthermore when discussing fiduciary risk Ritva Rainikka at the World Bank says "there is no clear evidence that the risk is greater for budget support than project aid" (Reinikka, 2008). Countries receiving budget support also often receive assistance to improve their financial managements systems and in fact according to the World Bank "To reduce fiduciary risks associated with budget support, PRSCs were intended to strengthen domestic budget processes." (World Bank 2010a, p. xiii).

\section{Economic policy and growth}

If a donor country that is using project approach decides to change its approach and get involved in budget support operations, in addition to the project approach, there needs to be some certainty, or at least a reasonable likelihood, that good economic policy and good governance leads to stronger economic growth. If engaged in policy dialogue with partner countries the Baltic States would also want to see results and increased effectiveness of their aid programs in partner countries.

The so called Washington Consensus attempted to summarize the outcome of the debate on what policy stances are conducive to economic development ${ }^{16}$ (Williamson, 2000; Center for International Development, Harvard University, 2003). Although there is empirical evidence to support many of the policies in the Washington Consensus the international financial institutions were heavily criticised during the 1980s and the early 1990s for interpreting the policy prescription too literally, without country specific circumstances, institutional conditions, or effects on poverty.

There continues to be a debate about the relationship between good policy environment and economic growth. C. Burnside and D. Dollar (2000) published a famous article a decade ago where the case was made that aid had positive impact on economic growth in countries with good economic policies (Burnside and Dollar, 2000). They concluded that making aid more systematically conditional on the quality of policies would likely increase its 
impact on developing countries growth. Other authors have been more cautious in concluding that aid promotes growth in countries with sound policies (see for example Easterly, Levine and Roodman, 2004) and emphasize that the seminal paper of C. Burnside and D. Dollar (2000) does not provide the final answer on this critical issue.

The debate on the relationship between economic policies and growth is likely to be ongoing for a very long time, and it is safe to say that we do not know with any certainty which policies are most conducive to economic growth and poverty alleviation. However, while no one has found a "magic bullet" for growth there are some things that seem important, including sensible macroeconomic management ${ }^{17}$; laws and policies that create an environment conducive to private sector activity with low transaction costs; and an economy open for international trade (see, for example, Rajan, 2005). Investment in health and education also ought to be encouraged. The emphasis on macroeconomic stability and outward orientation in the Washington Consensus, have been and still remain, important components of sustainable development strategies.

In 2008 the so called Commission on Growth and Development issued a report titled: The Growth Report - Strategies for Sustained Growth and Inclusive Development. The report identified some of the distinctive characteristics of high growth and asked how other countries can emulate them. This report drew inspiration from economies that had been able to sustain growth at an average of $7 \%$ or more for 25 years or longer. Those successful economies had five common features that were summarized in a report that followed in 2010: (i) they fully exploited the world economy, (ii) they maintained macroeconomic stability, (iii) they mustered high rates of investment, (iv) in allocating resources, these economies paid due respect to market signals, and (v) as a complement to these functioning markets, the successful economies also committed, credible and capable governments. As the commission stated these characteristics are easy to identify but harder to know how to replicate them in new places and new circumstances. In fact the commission stated that it „does not provide a formula for policy makers to apply - no generic formula exists" (Commission on Growth and Development, 2008, p. 2). According to the report governments should be pragmatic in their pursuit of high growth and the Commission stated that „If there were just one valid growth doctrine, we are confident we would have found it" (Commission on Growth and Development, 2008, p. 4). The report encourages governments to pursue an experimental growth to the implementation of economic policy and cites Deng Xiaoping "cross the river by feeling the stones." In the 2008 report the commission stated that growth can be explained and expressed the hope that it can be repeated. The report was written just before the crisis and in a follow up report in 2010 the commission acknowledged that two ingredients that needed most rethinking was financial reform and export promotion. However the commission was of the view that the growth model in the original report still remained the best strategy to follow (Commission on Growth and Development, 2010).

According to the Commission on Growth and Development there exist some guidelines on what constitutes good economic policy. Those guidelines summarized by the commission can presumably 
be used both by governments implementing reforms as well as by donors supporting reforms and engaging in policy dialogue with partner governments. In addition to this the Baltic States had periods of strong growth after EU accession and are now back on a growth track. They can share this experience, in addition to their response to the global crisis that started in the fall of 2008 and hit them hard, especially Latvia.

\section{Conclusions}

The Baltic States have all successfully implemented major economic transitions during the last two decades. They are now firmly integrated in the global economy and are members of key international organizations including the EU, NATO, WTO, WBG, EBRD, etc. They have also initiated their bilateral development programs and selected partner countries as well as priority areas/sectors.

In spite of the recent economic and financial crisis, public support for international development cooperation is rather strong in the Baltic States, although public awareness about the projects and partner countries selected remains low. All the Baltic States fall short of fulfilling EU targets for EU10 countries as percentage of GNI.

Small countries such as the Baltic States cannot currently contribute large amounts of funds to international development cooperation. Their transition experience can however be valuable. Latvia and Lithuania are already upper middle income countries, and Estonia has reached high income status. Those countries can become important contributors to the policy dialogue in their partner countries where they can share their experience, successes and failures. In doing so, their influence and effectiveness could be enhanced by working in partnership with international financial institutions and other bilateral donors. Currently the Baltic States mainly assist middle income countries further to the south and east, in Europe and Central Asia. The Baltic States can for example advise transition countries on public administration reform, institution building, European integration, etc. The Baltic States already contribute to budget support operations multilaterally through their EU membership and contributions to the World Bank.

Due to EU commitments to increase their contributions to development cooperation, and projected economic growth in the next few years, the aid volumes of the Baltic States are likely to increase substantially. Shifting some of their assistance from project approach to budget support in an option they need to consider.

When small countries such as the Baltic States act alone their influence is likely to be rather limited. For small donor countries projects can certainly allow them plant their flag and to better control the use of their money. But in the big picture of things, the impact of small projects can be quite marginal. Policy lending under a PRSC-like umbrella gives small donors a seat at the table for the policy dialogue. However a small country would probably be more effective if it focuses only on a few key policy actions. A small donor country may also increase its impact by combining involvement in budget support with technical assistance for the ministries or agencies in charge of those key policy actions. The partner country receiving the technical assistance can then rely on the products of that technical assistance as an input in the policy dialogue, and on technical assistance program itself to deliver on the policy actions. 
Some of the partner countries of the Baltic States are receiving budget support and are engaged in policy dialogue with the World Bank, in partnership and with support from the European Union, other multilateral development institutions as well as bilateral donors. This is done via Development Policy Loans/Operations, DPL/DPO. The Baltic States have so far not participated in such partnerships

Participation in budget support operations should not be seen as a panacea and does not guarantee success. Budget support instruments can however be very useful for dialogue on government wide policy issues and economic reforms in the recipient country. Provision of technical assistance, including in financial management, is necessary for developing and transition economies receiving budget support and can enable them to use government systems more effectively. Using project approach and budget support should not be seen as an "either/ or" choice. Both types of assistance can be used simultaneously and budget support could be introduced gradually especially for the recipient countries with the weakest country systems. To achieve poverty reduction in the long-term, sustainable economic growth is necessary. Budget support operations can support economic policies that are conducive to economic growth.

\section{Notes}

1 Most of the discussion in this article is on the Baltic States (Estonia, Latvia and Lithuania). The Nordic countries Denmark, Norway and Sweden are not discussed in any detail but the article refers to them as examples of small states who have managed to become leaders in international development cooperation. The Baltic States could possible learn lessons from those countries.

2 In fact, multilaterally, the Baltic States already are budget support providers through their membership in the European Union as well as the World Bank's International Development Association.

3 In addition to this, one of the Baltic States, Estonia in also a member of OECD and part of the Euro zone.

4 In fact the only other countries that have achieved this status are the Netherlands and Luxembourg who also are small states.

5 The regional development banks are the Asian Development Bank (AsDB), the African Development Bank (AfDB) and the Inter-American Development Bank (IDB).

6 That group of countries also includes Ireland and FYR Macedonia.

7 According to the 2010 survey $89 \%$ of Lithuanians, $86 \%$ of Latvians and $84 \%$ Estonians considered it important "to help people in developing countries." However, 38 \% of Lithuanians, $33 \%$ of
Latvians and $32 \%$ of Estonians considered it very important "to help people in developing countries" (European Commission, 2010, p. 9).

8 In 1980 the World Bank introduced its first structural adjustment loan which marked a shift from project aid to program based approach, where policy conditionality played an important role. Since then there has been a substantial shift in the international institutional environment for development cooperation and a number of important donor meetings have taken place, and declarations issued on aid effectiveness. Among those are: the Copenhagen Summit in 1995, the Millennium Development Goals from 2000, the Monterrey Consensus 2002, the Rome and Paris Declarations on Aid Efficiency from 2003 and 2005, and the Roundtables on Managing for Development Results (These roundtables were organized by the World Bank and took place in Washington DC 2002, in Marrakesh in 2004, and in Hanoi 2007). World Bank's Comprehensive Development framework launched in 1999 is a notable change in the World Bank's development approach and the OECD DAC guidelines are also important. As a result, the key words in the current development paradigm are: ownership, alignment, harmonization, and results orientation. This has also resulted in increased emphasis on budget support to recipient countries and in creating an overall policy environment conducive to 
long-term growth.

9 According to an email to the author from the Ministry of Foreign Affairs in Estonia dated April $25,2011$.

10 According to an email to the author from the Ministry of Foreign Affairs in Latvia dated April 26, 2011.

11 According to the website of the Ministry of Foreign Affairs in Lithuania accessed April 27, 2011, available at: http://www.urm.lt/index. php?699487924.

12 According to an email to the author from the Ministry of Foreign Affairs in Estonia dated March 26, 2012.

13 According to an email to the author from the Ministry of Foreign Affairs in Lithuania dated March 29, 2012.

14 According to an email to the author from the Ministry of Foreign Affairs in Lithuania dated April 27, 2011.

15 The Independent Evaluation Group (IEG) is charged with evaluating the activities of IBRD and IDA (the World Bank), the work of IFC in private sector development, and MIGA's guarantee projects and services. The Director-General of IEG reports directly to the World Bank Group's Board of Directors. The goals of evaluation are to provide an objective assessment of the results of the Bank Group's work and to identify and disseminate lessons learned from experience.

16 In its original formulation, the Washington Consensus prescribed a policy that could be summarized in ten propositions as follows: (i) fiscal discipline, (ii) a redirection of public expenditure priorities toward fields offering both high economic returns and the potential to improve income distribution, such as primary health care, primary education, and infrastructure, (iii) tax reform (to lower marginal rates and broaden the tax base), (iv) interest rate liberalization, (v) a competitive exchange rate, (vi) trade liberalization, (vii) liberalization of FDI inflows, (viii) privatization, (ix) deregulation (in the sense of abolishing barriers to entry and exit), (x) secure property rights.

17 This would for example include: Fiscal discipline, moderate inflation, and a reasonable competitive exchange rate.

\section{References}

1. Andrespok, E., Kasekamp, A. I. (2012). Development Cooperation of the Baltic States: A Comparison of the Trajectories of Three New Donor Countries // Perspectives on European Politics and Society. Vol. 13, No. 1, pp. 117-130. doi: 10.1080/15705854.2011.649166.

2. Burnside, C., Dollar, D. (2000). Aid, Policies, and Growth // American Economic Review. Vol. 90, No. 4, pp. 847-68. doi: 10.1257/aer.90.4.847.

3. Center for International Development, Harvard University (2003). Washington Consensus. Internet access: <http://www.cid.harvard.edu/cidtrade/issues/washington.html $>$, [accessed February 20, 2012].

4. Commission on Growth and Development (2008). The Growth Report Strategies for Sustained Growth and Inclusive Development. International Bank for Reconstruction and Development / The World Bank 2008. Internet access: $<$ http://cgd.s3.amazonaws.com/GrowthReportComplete.pdf $>$, [accessed July 19, 2011]. doi: 10.1596/978-0-8213-7491-7.

5. Commission on Growth and Development (2010). Post-Crisis Growth in Developing Countries. A Special Report of the Commission on
Growth and Development on the Implications of the 2008 Financial Crisis. International Bank for Reconstruction and Development / The World Bank 2010. Internet access: <http://www.growthcommission.org/storage/cgdev/documents/ specialreport/specialreportfullversion.pdf $>$, [accessed July 20, 2011]. doi: 10.1596/978-08213-8165-6.

6. Council of the European Union (2012). Council conclusions on Annual Report 2012 to the European Council on EU Development Aid Targets. Internet access: <http://www.consilium. europa.eu/uedocs/cms_data/docs/pressdata/EN/ foraff/130239.pdf >, [accessed October 18, 2012].

7. Easterly, W., Ross, L., Roodman, D. (2004). Aid Policies and Growth: Comment // American Economic Review. Vol. 94, No. 3, pp. 774-80. doi: 10.1257/0002828041464560.

8. Estonian Government. (n.d.). Strategy for Estonian Development Cooperation and Humanitarian Aid 2011-2015. Internet access: <http:// www.vm.ee/sites/default/files/Arengukava20112015_ENG.pdf> [accessed September 20, 2012].

9. European Bank for Reconstruction and Development (2011). Directors of the EBRD. Internet 
access: <http://www.ebrd.com/pages/about/who/ structure/directors.shtml $>$, [accessed May 26, 2011].

10. European Commission (2008). Budget support 'A question of mutual trust.' Internet access: <http:// ec.europa.eu/development/icenter/repository/ LM_budget_support_en.pdf>, [accessed June 10, 2011].

11. European Commission (2010). European, development aid and the Millennium Development Goals. Special Eurobarometer, 352. Internet access: <http://ec.europa.eu/public_opinion/ archives/ebs/ebs_352_en.pdf $>$, [accessed September 22, 2012].

12. European Commission (2012). Solidarity that spans the globe: Europeans and development aid, 392. Internet access: <http://ec.europa.eu/ public_opinion/archives/ebs/ebs_392_en.pdf>, [accesse September 26, 2012].

13. Hilmarsson, H. T. (2011). The Baltic States and their transition from being recipient countries to becoming donor countries. Paper presented at the 9th Baltic studies conference in Europe, Södertörn University, Stockholm, 12-15 June 2011.

14. Koeberle, S., Stavreski, Z. (2006). Budget Support: Concept and Issues. In Budget Support as More Effective Aid? Recent Experience and Emerging Lessons. International Bank for Reconstruction and Development. - World Bank, Washington, DC. doi: 10.1596/978-0-8213-6463-5.

15. Leyser, L. (2008). Does Size Really Matter? Small Bilateral Donors and Program-Based Approaches (PBAs) - exemplified by Austria and Ireland. $12^{\text {th }}$ EADI General Conference, Global Governance for Sustainable Development. Internet access: <http://www.eadi.org/fileadmin/Documents/ Events/General_Conference/2008/paper_leyser. pdf $>$, [accessed March 20, 2011].

16. Ministry of Foreign Affairs, Estonia (2012). Estonian Development Co-operation - Priority Partner Countries. Internet access: <http://www. vm.ee/?q=en/taxonomy/term/55>, [accessed October 12, 2012].

17. Ministry of Foreign Affairs, Latvia (2012). Development Co-operation Priority Countries. Internet access: <http://www.mfa.gov.lv/en/policy/ DevelopmentCo-operation/info/>, [accessed October 12, 2012].

18. Ministry of Foreign Affairs, Lithuania. (2012). Lithuanian Priority Partner Countries. Internet access: <http://www.urm.lt./index.php? 343958539>, [accessed October 12, 2012].

19. OECD (2006a). DAC Guidelines and Reference
- Series Harmonising Donor Practices for Effective Aid Delivery - Volume 2. Internet access: <http://www.aideffectiveness.org/ media/k2/attachments/Dac_2__SWAP_PFM_ BUDGET_1.pdf>, [accessed July 21, 2011].

20. OECD (2006b). Should OECD Donors Deliver Aid Through Poor Country Governments Budgets? Internet access: <http://www.oecd.org/ dataoecd/16/31/36644712.pdf >, [accessed July 10, 2011].

21. Rajan, R. (2005). Aid and Growth: The Policy Challenge // Finance \& Development. No. 42, Vol. 4. pp. 53-55.

22. Reinikka, R. (2008). Donors and Service Delivery. In Reinventing Foreign Aid, Edited by William Easterly. - The MIT Press, Cambridge, Massachusetts.

23. Williamson,J.(2000). WhatShould the WorldBank Think about the Washington Consensus? Internet access: <http://www.iie.com/publications/ papers/print.cfm?doc $=$ pub \&ResearchID $=351>$, [accessed September 29, 2012].

24. World Bank (2009). Country Partnership Strategy for Georgia for the period FY10-FY13. Internet access: http://siteresources.worldbank. org/GEORGIAEXTN/Resources/3017451240578037641/GE_CPS_Final.pdf>, [accessed September 12, 2012].

25. World Bank (2010a). Poverty Reduction Support Credits: An Evaluation of World Bank Support, available at: <http://siteresources.worldbank.org/ INTPRSC/Resources/prsc_eval.pdf >, [accessed June 15, 2010]. doi: 10.1596/978-0-8213-8305-6.

26. World Bank (2010b). Program document for a proposed economic recovery development policy credit to the Republic of Moldova. Internet access: <http://www-wds.worldbank.org/external/default/WDSContentServer/WDSP/IB/2010 /10/19/000333038_20101019233323/Rendered/ PDF/526690revised0111010IDAR20101018312. pdf $>$, [accessed September 12, 2012].

27. World Bank (2012a). Doing Business 2013 Smarter Regulations for Small and MediumSize Enterprises. Internet access: <http:// doingbusiness.org/reports/global-reports/doingbusiness-2013>, [accessed October 23, 2012]. doi: 10.1596/978-0-8213-9615-5.

28. World Bank (2012b). EU11 Regular Economic Report. Coping With External Headwinds. Internet access: <http://www-wds.worldbank.org/ external/default/WDSContentServer/WDSP/IB /2012/06/28/000356161_20120628035037/Rendered/PDF/699660REVISED00omic0Report0Fi 
nal0V2.pdf>, [accessed September 12, 2012].

29. World Bank (2012c). Country partnership strategy for Ukraine for the period FY12-FY16. Internet access: <http://siteresources.worldbank.org/UKRAINEEXTN/Resources/328532-
1328450253285/full_report_ENG.pdf>, [accessed September 12, 2012].

30. Yin, R. K. (2009). Case Study Research - Design and Methods. Applied Social Research Methods Series. $4^{\text {th }}$ edition. - Sage Inc. California.

The paper submitted: April 12, 2013

Prepared for publication: September 1, 2013

Hilmar Thor HILMARSSON

\section{BALTIJOS VALSTYBÉS IR TARPTAUTINIO VYSTYMOSI BENDRADARBIAVIMAS: KAIP GERIAUSIAI PASIDALINTI SAVO PATIRTIMI SU MAŽIAU IŠSIVYSČIUSIOMIS PEREINAMOJO LAIKOTARPIO ŠALIMIS?}

\section{$\mathrm{S}$ a n t r a u a}

Nepaisant daugybės iššūkių, kuriuos Baltios valsybės patyrè per dabartinę ekonomikos ir finansų krizę, jų progresas nuo $1991 \mathrm{~m}$. yra žymus. Per maždaug du dešimtmečius šios šalys transformavosi iš planinès ekonomikos ir Sovietų Sąungos dalinio ị modernias valstybes, kurios yra stipriai integruotos i t pasaulinę ekonomiką. Nuo nepriklausomybès metų jos tapo Europos Sąungos (ES), NATO ir Pasaulio prekybos organizacijos (PPO) naremis. Jos taip pat yra Pasaulio banko grupès (PBG) bei Europos Rekonstrukcijos ir Plètros Banko (ERPB) narès. Remiantis Pasaulio Banko klasifikacija Latvija ir Lietuva yra didesnes nei vidutines pajamas gaunančios šalys, o Estija pasiekẻ aukštas pajamas gaunančios valstybès statusą.

Baltijos valstybėms svarstant ir vystant užsienio pagalbos programas gali būti naudinga peržiūrèti kaimyninių valstybių patirtis, ką iš jų būtų galima pasimokyti. Daugiašališkai Šiaurès ir Baltijos valstybès bendradarbiauja plačiai. Pasaulio banko grupeje Baltijos valstybès kartu su Šiaurès šalimis dalinasi vykdomojo direktoriaus funkciją. Šiaurès ir Baltijos šalių bendradarbiavimas taip pat apima Europos rekonstrukcijos ir plètros banką (ERPB). ERPB Islandija dalinasi su Estija ir Švedija, Latvija dirba su Norvegija ir Suomija, galiausiai Lietuva dirba kartu su Danija. Šiaurès šalys, ypač Danija, Norvegija ir Švedija, yra lyderiai tarptautinio vystymosi bendradarbiavime ir kaip grupe gali turèti ittakos plètros politikai bei visai plètrai pasauliniame lygmenyje. Šiaurès šalys bendradarbiaudamos su Baltijos valstybèmis taip pat galètų pasinaudoti Baltijos šalių patirtimi, sèkmingai igyvendinus ekonomines reformas.

Šio straipsnio objektas yra ịvertinti, kokị vaidmenị mažos valstybès gali turèti savo šalių partnerių atžvilgiu, stengiantis igyvendinti pereinamojo laikotarpio ekonomiką bei siekiant ekonomikos augimo ir skurdo mažinimo. Straipsnyje daugiausiai analizuojamos Baltijos šalys. Kaip aptarta anksčiau, visos šios valstybès yra dalyviai daugiašalèse institucijose ir teikia dvišalę pagalbą šalims partnerèms. Tačiau kaip šios valstybès, būdamos mažos šalys, turètų padèti savo šalims partnerèms ateityje? Kaip Baltijos valstybès gali geriausiai pasidalinti savo pereinamojo laikotarpio patirtimi su mažiau išsivysčiusiomis pereinamojo laikotarpio šalimis? Ar jos turètų sutelkti dèmesị i mažus dvišalius projektus ar jos turètų bendradarbiauti su kitais dvišalių ir daugiašalių junginių donorais? Ar jos turètų vykdyti biudžeto paramos operacijas ir dalyvauti politiniame dialoge, ar sutelkti dèmesị i mažus projektus, ar vykdyti abiejų šių priemonių derinį?

Straipsnio tikslas yra atkreipti Baltijos valstybių politikos formuotojų dèmesị, rengiant jų plètros programas bei atkreipiant demesị ì naujausias tendencijas tarptautinio bendradarbiavimo vystomosi procese. Studijuojant šias tendencijas bei metodus, kuriais mažos valstybės, ịskaitant Šiaurès šalis, igyvendino savo vystymosi programas, gali padèti Baltijos šalims padidinti savo programų efektyvumą. Kitas straipsnio tikslas yra prisideti prie akademinès Baltijos šalių tarptautio bendradarbiavimo vystymosi literatūros. Kol kas literatūra šioje tematikoje yra ribota, todèl daugiau tyrimų bei diskusijų Baltijos šalių mokyklose padètų politikams formuojant programas ateityje

Tyrimui atlikti yra naudojamas atvejo tyrimo metodas - lyginamasis atvejo tyrimas, apimantis tris Baltijos valstybes. Tyrimas grindžiamas moksline literatūra, interviu, elektroninio pašto laiškais, antrinių duomenų ir autoriaus ankstesne patirtimi, dirbant Pasaulio banko grupès nariu ir specialiuoju Islandijos užsienio reikalų ministro patarèju. 
Vienoje iš straipsnyje pateikiamų išvadų yra pažymima, jog mažoms šalims, tokioms kaip Baltijos valstybès, veikiant savarankiškai, jų i taka tampa gana ribota. Mažoms valstybėms donorèms projektai leidžia geriau kontroliuoti savų pinigų panaudojimą. Tačiau bendrame paveiksle mažų projektų poveikis gali būti nedidelis. Todèl mažoms valstybèms yra veiksmingiau orientuotis tik ị keletą pagrindinių politikos formavimo veiksmų. Maža šalis donore taip pat gali padidinti savo įtaką, derindama dalyvavimą biudžeto paramos teikime kartu su technine pagalba ministerijoms ar agentūroms, atsakingoms už pagrindinius politikos formavimo veiksmus.

Dalyvavimas biudžeto paramos operacijose neturètų būti vertinamas kaip panacèja ir negarantuoja sẻkmès. Biudžetinès paramos priemonès vis dèlto gali būti labai naudingos vyriausybių dialogo lygmenyje politikos klausimais ir igyvendinant ekonomikos reformas naudą gaunančiose šalyse. Techninès pagalbos teikimas, įskaitant finansų valdymą, yra būtinas besivystančioms ir pereinamojo laikotarpio ekonomikoms, gaunant biudžeto paramą ir suteikia galimybes panaudoti vyriausybines sistemas efektyviau. Projektų ir biudžeto paramos panaudojimas neturètų būti suvokiamas kaip“ arba / arba „ pasirinkimas. Abi pagalbos rūšys gali būti naudojamos kartu ir biudžeto parama gali būti ịvedama palaipsniui, ypač paramą gaunančių šalių atveju. Siekiant mažinti ilgalaikị skurdą, tvarus ekonomikos augimas yra būtinas. Biudžeto paramos operacijos gali paremti ekonomikos politiką, prisidedančią prie ekonomikos augimo. 